\title{
Lactobacillus saniviri sp. nov. and Lactobacillus senioris sp. nov., isolated from human faeces
}

Correspondence

Koichi Watanabe

koichi-watanabe@yakult.co.jp

\author{
Kaihei Oki, Yuko Kudo and Koichi Watanabe
}

\author{
Yakult Central Institute for Microbiological Research, 1796 Yaho, Kunitachi, Tokyo 186-8650, \\ Japan
}

Two Gram-stain-positive strains, YIT $12363^{\top}$ and YIT $12364^{\top}$, were isolated from human faeces. They were rod-shaped, non-motile, asporogenous, facultatively anaerobic and did not exhibit catalase activity. Comparative analyses of $16 \mathrm{~S}$ rRNA, pheS and rpoA gene sequences demonstrated that the novel strains were members of the genus Lactobacillus. On the basis of 16S rRNA gene sequence similarity, the type strains of Lactobacillus casei ( $95.3 \%$ similarity), Lactobacillus paracasei subsp. paracasei (95.6\%), Lactobacillus paracasei subsp. tolerans (95.3\%) and Lactobacillus rhamnosus (95.4\%) were the closest neighbours to strain YIT $12363^{\top}$. For strain YIT $12364^{\top}$, the highest similarity values were observed with the type strains of Lactobacillus diolivorans, Lactobacillus parafarraginis and Lactobacillus rapi $(95.8,96.0$ and $96.0 \%$, respectively). Phenotypic and genotypic features demonstrated that these strains each represent a separate novel species of the genus Lactobacillus, and the names Lactobacillus saniviri sp. nov. (type strain YIT $12363^{\top}=\mathrm{JCM} 17471^{\top}=\mathrm{DSM} 24301^{\top}$ ) and Lactobacillus senioris sp. nov. (type strain YIT $12364^{\top}=\mathrm{JCM} 17472^{\top}=\mathrm{DSM} 24302^{\top}$ ), respectively, are proposed.
Lactobacillus strains are among the most familiar microorganisms to humans, not only because of their association with a wide range of naturally fermented dairy products, grain crops and vegetables but also because they inhabit the gastrointestinal tracts of humans and animals, and are the most widely used probiotics aimed at promoting a healthy lifestyle. Currently, the genus Lactobacillus comprises about 140 species, although only a few species - Lactobacillus brevis, the Lactobacillus casei group, Lactobacillus delbrueckii, Lactobacillus gasseri, Lactobacillus parabuchneri, the Lactobacillus plantarum group, Lactobacillus reuteri and Lactobacillus sakei - have been found in human faeces (Dal Bello et al., 2003; Walter, et al., 2001). Although the names of around 80 species have been validly published in the last decade, no novel species isolated from human faeces

The GenBank/EMBL/DDBJ accession numbers for the 16S rRNA gene sequences of strains Lactobacillus saniviri sp. nov. YIT $12363^{\top}$ and Lactobacillus senioris sp. nov. YIT $12364^{\top}$ are AB602569 and $A B 602570$, respectively; those for the pheS gene sequences are $A B 602775$ and $A B 602776$, respectively; and those for the rpoA gene sequences are AB602777 and AB602778, respectively. Accession numbers for the pheS gene sequences of $L$. camelliae YIT $12276^{\top}, L$. farraginis YIT $12273^{\top}$, L. kisonensis YIT $11168^{\top}$, L. otakiensis YIT $11163^{\top}$, L. parafarraginis YIT $12274^{\top}$, L. rapi YIT $11204^{\top}$ and L. sunkii YIT $11161^{\top}$ are AB602819-AB602825, respectively; and those for the rpoA gene sequences are AB602828-AB602834, respectively. Accession numbers for the rpo $A$ gene sequences of $L$. buchneri YIT $0077^{\top}$ and L. diolivorans YIT $10368^{\top}$ are AB602826 and AB602827, respectively.

Three supplementary figures are available with the online version of this paper. have been described during this time (J. P. Euzéby: List of Prokaryotic names with Standing in Nomenclature; http:// www.bacterio.cict.fr/index.html).

While exploring novel Lactobacillus strains from the culture collection of the Yakult Central Institute, 328 strains isolated from the faeces of 61 healthy Japanese subjects in different age-groups - neonates, infants, adults, elderly people and centenarians - were reanalysed by determining 16S rRNA gene sequence similarity values and using DNA-DNA hybridization tests. As a result, two strains that could not be clearly placed within any recognized species of the genus Lactobacillus were discovered. In the present study, further phenotypic and genotypic research revealed that strains YIT $12363^{\mathrm{T}}$ and YIT $12364^{\mathrm{T}}$ represent two novel species of the genus Lactobacillus. The following Lactobacillus strains were obtained from the culture collection of Yakult Central Institute (YIT, Tokyo, Japan) and were used as references: $L$. casei YIT $0078^{\mathrm{T}}$, Lactobacillus paracasei subsp. paracasei $\mathrm{YIT}$ $0209^{\mathrm{T}}$ and Lactobacillus rhamnosus YIT $0105^{\mathrm{T}}$ (for isolate YIT $12363^{\mathrm{T}}$ ); and Lactobacillus parafarraginis YIT $12274^{\mathrm{T}}$ and Lactobacillus rapi YIT $11204^{\mathrm{T}}$ (for isolate YIT $12364^{\mathrm{T}}$ ). The strains used in this study were cultivated and maintained in MRS broth (BD, Difco; pH 6.8) (De Man et al., 1960) at $37{ }^{\circ} \mathrm{C}$ ( or $30{ }^{\circ} \mathrm{C}$ for L. parafarraginis YIT $12274^{\mathrm{T}}$ ) for $16 \mathrm{~h}$, unless indicated otherwise. Modified MRS broth [MRS broth supplemented with $1 \%(\mathrm{w} / \mathrm{v})$ L-arabinose and $1 \%(\mathrm{w} / \mathrm{v})$ maltose instead of glucose] was used for L. rapi YIT $11204^{\mathrm{T}}$.

Chromosomal DNA used as a template for 16S rRNA, rpoA and pheS gene sequence amplification was prepared 
according to the method of Watanabe et al. (2008). The conditions for PCR amplification of the partial 16S rRNA gene and subsequent DNA sequencing have been described previously (Chao et al., 2008). The pheS and rpoA gene sequences for YIT $12363^{\mathrm{T}}$, YIT $12364^{\mathrm{T}}$, Lactobacillus buchneri YIT $0077^{\mathrm{T}}$ (rpoA gene only), Lactobacillus camelliae YIT $12276^{\mathrm{T}}$, Lactobacillus diolivorans YIT $10368^{\mathrm{T}}$ (rpoA gene only), Lactobacillus farraginis YIT $12273^{\mathrm{T}}$, Lactobacillus kisonensis YIT $11168^{\mathrm{T}}$, Lactobacillus otakiensis YIT $11163^{\mathrm{T}}$, L. parafarraginis YIT $12274^{\mathrm{T}}$, L. rapi YIT $11204^{\mathrm{T}}$ and Lactobacillus sunkii YIT $11161^{\mathrm{T}}$ were amplified by PCR with primers rpoA-21F ( $5^{\prime}$-ATGATYGARTTTGAAAAAACC-3') and rpoA-23R (5'-ACHGTRTTRATDCCDGCRCG-3') (Naser et al., 2005), and pheS-21F (5'-CAYCCNGCHCGYGAYATGC- $3^{\prime}$ ) and pheS-952R (5'-TATTTCAAAATTGCRAAACGRTC-3') (for YIT $12363^{\mathrm{T}}$, YIT $12364^{\mathrm{T}}$ ) or pheS-23R (5'-GGRTGTACCATVCCNGCHCC-3') (Naser et al., 2005), respectively. The PCR mixture $(25 \mu \mathrm{l})$ contained $1 \times$ Ex Taq Buffer, $200 \mu \mathrm{M}$ of each dNTP, $0.4 \mu \mathrm{M}$ of each primer, $1 \mathrm{U}$ Ex Taq HS polymerase (Takara Bio) and 10 ng template DNA. The amplification program consisted of: one cycle of $95{ }^{\circ} \mathrm{C}$ for $2 \mathrm{~min}$; 35 cycles of $95{ }^{\circ} \mathrm{C}$ for $20 \mathrm{~s}, 55^{\circ} \mathrm{C}$ (for phes gene) or $46{ }^{\circ} \mathrm{C}$ (for rpoA gene) for $30 \mathrm{~s}, 72{ }^{\circ} \mathrm{C}$ for 1 min $15 \mathrm{~s}$; and finally one cycle of $72{ }^{\circ} \mathrm{C}$ for $3 \mathrm{~min}$. For amplification of the pheS gene of strains YIT $12363^{\mathrm{T}}$ and YIT $12364^{\mathrm{T}}, 1 \times \mathrm{Taq}$ buffer and Taq polymerase (Takara Bio) were used and the annealing temperature was changed to $42{ }^{\circ} \mathrm{C}$. For amplification of the pheS gene of L. rapi YIT $11204^{\mathrm{T}}$, the annealing temperature was changed to $42{ }^{\circ} \mathrm{C}$. For amplification of the rpoA gene of L. farraginis YIT $12274^{\mathrm{T}}$, the annealing and elongation steps were modified to $48{ }^{\circ} \mathrm{C}$ for $20 \mathrm{~s}$ and $72{ }^{\circ} \mathrm{C}$ for $5 \mathrm{~s}$, respectively.

The amplified 16S rRNA, pheS and rpoA genes were purified by using an AMPure kit (Beckman Coulter) and were subsequently sequenced using the ABI PRISM BigDye Terminator v3.1 cycle sequencing kit (Applied Biosystems). The closest known species to the novel isolates were determined by FASTA and sequences of members of the most closely related species were extracted from GenBank/EMBL/ DDBJ. Multiple alignment and the construction of phylogenetic trees were performed with the program CLUSTAL_X v. 2.0.12. (Thompson et al., 1997). For strain YIT $12363^{\mathrm{T}}$, strain YIT $12364^{\mathrm{T}}$ and related strains, approximately $1390 \mathrm{bp}$ of the 16S rRNA gene, approximately $280 \mathrm{bp}$ of the pheS gene and approximately $350 \mathrm{bp}$ of the $r p o A$ gene sequences were used for constructing phylogenetic trees by the neighbourjoining method (Saitou \& Nei, 1987). The statistical reliability of trees was evaluated by bootstrap analysis of 1000 replicates (Felsenstein, 1985) and tree topologies were also confirmed with the minimum-evolution (Rzhetsky \& Nei, 1992) and maximum-parsimony (Fitch, 1971) methods, by using MEGA v4.1 software (Tamura et al., 2007), according to the Kimura two-parameter model (Kimura, 1980).

Phylogenetic analysis based on 16S rRNA gene sequences showed that isolate YIT $12363^{\mathrm{T}}$ was a close neighbour to the $L$. casei group of lactobacilli (Fig. 1). 16S rRNA gene sequence similarities between strain YIT $12363^{\mathrm{T}}$ and its closest neighbours, L. casei YIT $0078^{\mathrm{T}}$, L. paracasei subsp. paracasei YIT $0209^{\mathrm{T}}$, L. paracasei subsp. tolerans NBRC $15906^{\mathrm{T}}$ and L. rhamnosus YIT $0105^{\mathrm{T}}$ were high, with values of 95.3, 95.6, 95.3 and 95.4\%, respectively. Similar topologies were obtained by the minimum-evolution (Supplementary Fig. S1, available in IJSEM Online) and maximum-parsimony (data not shown) methods. Similarities between the pheS and rpoA gene sequences of strain YIT $12363^{\mathrm{T}}$ and the most closely related strains ranged from 73.5 to $75.2 \%$, and from 79.5 to $80.4 \%$, respectively (Supplementary Figs S2 and S3, available in IJSEM Online). Phylogenetic analysis based on 16S rRNA gene sequences placed isolate YIT $12364^{\mathrm{T}}$ in the L. buchneri group of lactobacilli (Fig. 1). 16S rRNA gene sequence similarities between strain YIT $12364^{\mathrm{T}}$ and its closest neighbours, L. diolivorans YIT $10368^{\mathrm{T}}$, L. parafarraginis NRIC $0677^{\mathrm{T}}$ and $L$. rapi YIT $11204^{\mathrm{T}}$, were $95.8,96.0$ and $96.0 \%$, respectively; 16S rRNA gene sequence similarities with the type strains of all other species in this group were below $97 \%$. Similar topologies were obtained by the minimumevolution (Supplementary Fig. S1) and maximumparsimony (data not shown) methods. Similarities between the pheS and rpoA gene sequences of isolate YIT $12364^{\mathrm{T}}$ and the most closely related strains ranged from 77.3 to $79.9 \%$, and from 79.9 to $80.0 \%$, respectively (Supplementary Figs S2 and S3). Interspecies gaps within the genus Lactobacillus based on pheS and rpoA gene sequences normally exceed $10 \%$ and $5 \%$, respectively (Naser et al., 2007), which suggested that the novel strains should be classified as members of two novel species.

For determination of DNA-DNA relatedness and the DNA $\mathrm{G}+\mathrm{C}$ content, chromosomal DNA was extracted according to the method of Marmur (1961). DNA-DNA hybridization analyses were performed between strain YIT $12363^{\mathrm{T}}$, L. casei YIT $0078^{\mathrm{T}}$, L. paracasei subsp. paracasei YIT $0209^{\mathrm{T}}$ and L. rhamnosus YIT $0105^{\mathrm{T}}$, and between strain YIT $12364^{\mathrm{T}}$, L. parafarraginis YIT $12274^{\mathrm{T}}$ and L. rapi YIT $11204^{\mathrm{T}}$, respectively. The microdilution well technique was used as described by Ezaki et al. (1989) using a Spectra Max M2 (Molecular Devices) for fluorescence measurements. Reciprocal hybridization experiments were performed for every pair of strains at $44{ }^{\circ} \mathrm{C}$ (for YIT $12363^{\mathrm{T}}$ and its reference strains) or $40{ }^{\circ} \mathrm{C}$ (for YIT $12364^{\mathrm{T}}$ and its reference strains) for $2 \mathrm{~h}$ in the presence of $50 \%$ formamide, using biotinylated DNA and unlabelled ssDNA, which was bound non-covalently to microplate wells. The highest and lowest values of eight replicate wells were excluded and the mean of the remaining values was calculated for each experiment. The levels of DNA-DNA relatedness of strain YIT $12363^{\mathrm{T}}$ to $L$. casei YIT $0078^{\mathrm{T}}$, L. paracasei subsp. paracasei YIT $0209^{\mathrm{T}}$ and L. rhamnosus YIT $0105^{\mathrm{T}}$ were 22.330.0, 19.7-25.7 and 12.5-27.8\%, respectively; those of strain YIT $12364^{\mathrm{T}}$ to $L$. parafarraginis YIT $12274^{\mathrm{T}}$ and L. rapi YIT $11204^{\mathrm{T}}$ were $11.6-26.3$ and $15.9-23.1 \%$, respectively. All values among the reference strains were well below the $70 \%$ cut-off value that indicates separate species status (Stackebrandt \& Goebel, 1994). To assess the DNA G +C 


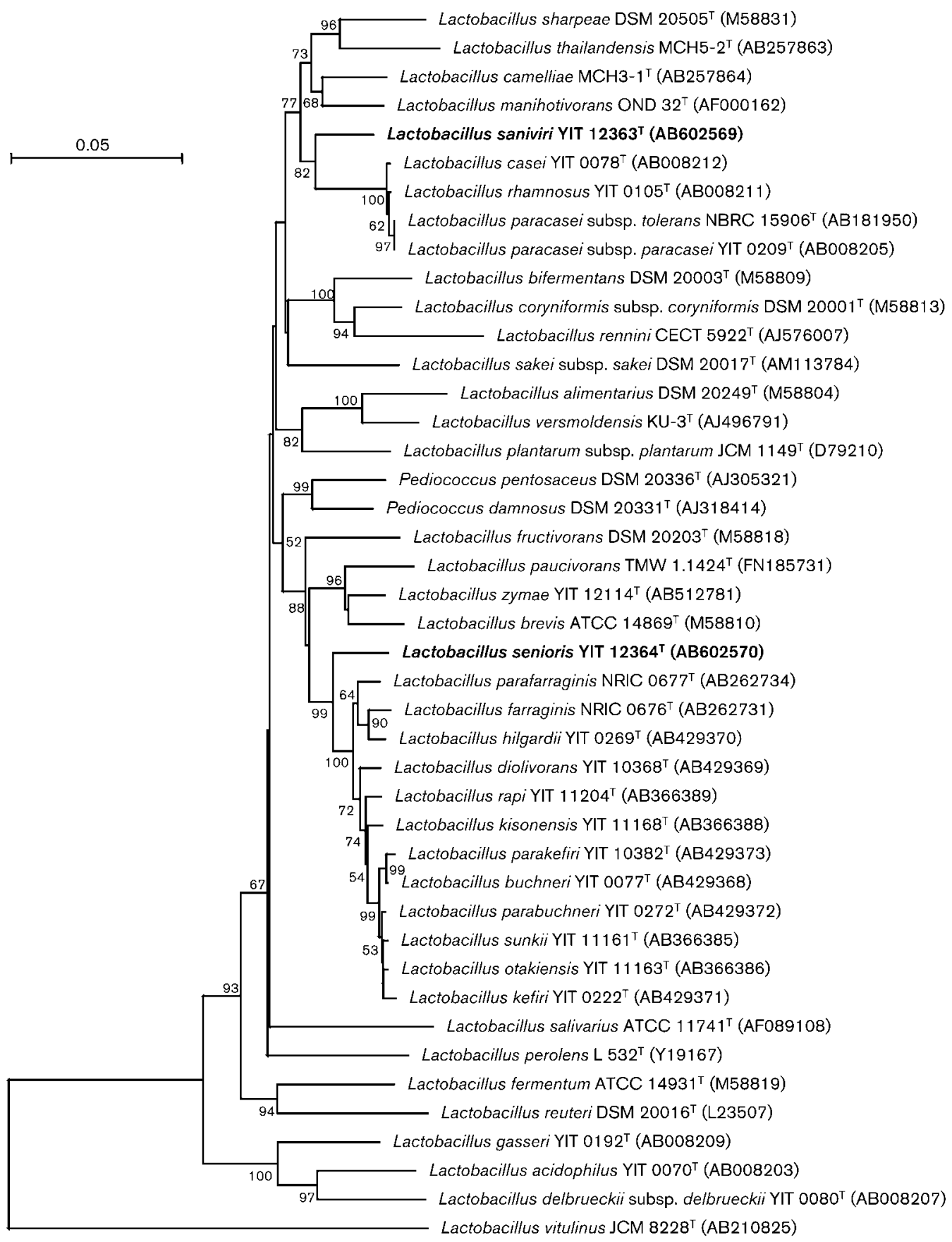

Fig. 1. Phylogenetic tree based on $16 \mathrm{~S}$ rRNA gene sequences showing the relationship of Lactobacillus saniviri sp. nov. YIT $12363^{\top}$ and Lactobacillus senioris sp. nov. YIT $12364^{\top}$ with strains of closely related species. The tree was constructed by the neighbour-joining method on the basis of a comparison of approximately $1390 \mathrm{bp}$, and Lactobacillus vitulinus $\mathrm{JCM}^{2} 228^{\top}$ was used as the outgroup. Bootstrap values (\%) based on 1000 replications are given at nodes. Bar, $5 \%$ sequence divergence.

content, DNA was enzymically degraded into nucleosides as described previously (Mesbah et al., 1989) and then separated by HPLC. The DNA G $+\mathrm{C}$ contents of strains YIT $12363^{\mathrm{T}}$ and YIT $12364^{\mathrm{T}}$ were 48.7 and $41.6 \mathrm{~mol} \%$, respectively, which are within the range for the genus Lactobacillus (32.0-53.0 mol\%) (Kandler \& Weiss, 1986).
Morphological, cultural and biochemical tests were performed according to standard techniques at $37^{\circ} \mathrm{C}$ unless otherwise stated. Cell shape, cell size and Gram staining were determined by using cultures grown in MRS broth at $37{ }^{\circ} \mathrm{C}$ for $16 \mathrm{~h}$. Motility was tested in MRS soft agar $(0.15 \%)$. Catalase activity was determined by using cells 
grown on MRS agar. Gas production from glucose was measured with a Durham tube in MRS broth. Production of dextran was assessed on MRS agar in which glucose was replaced with $2 \%(\mathrm{w} / \mathrm{v})$ sucrose. The methods of Barrow \& Feltham (1993) were used to determine growth at various temperatures and $\mathrm{pH}$, and in the presence of $\mathrm{NaCl}$, reduction of nitrate and production of ammonia from arginine. Carbohydrate fermentation tests were conducted by using the API 50 CHL system (bioMérieux) according to the manufacturer's instructions. The presence of diaminopimelic acid in the cell-wall peptidoglycan was determined according to Kandler \& Weiss (1986). Cell-wall peptidoglycan for analysis of amino acid composition was prepared and hydrolysed according to the method of Schleifer \& Kandler (1972). Cell-wall amino acids were analysed by HPLC (Alliance 2695 HPLC system; Waters) equipped with a fluorescence detector (model 474 Fluorescence Detector; Waters) and an AccQ-Tag column $(3.9 \times 150 \mathrm{~mm}$; Waters $)$, and using an AccQ-Fluor reagent KIT (6-aminoquinolyl- $N$ hydroxysuccinimidylcarbamate; Waters) for derivatization. Cellular fatty acid methyl esters were obtained from cells grown in MRS broth at $37{ }^{\circ} \mathrm{C}$ (or $30{ }^{\circ} \mathrm{C}$ for L. rapi YIT

Table 1. Differential characteristics of Lactobacillus saniviri sp. nov. YIT $12363^{\top}$ and closely related lactobacilli

Strains: 1, Lactobacillus saniviri sp. nov. YIT $12363^{\mathrm{T}} ; 2$, L. casei $\mathrm{YIT}_{0078^{\mathrm{T}}} ; 3$, L. paracasei subsp. paracasei YIT $0209^{\mathrm{T}}$; 4, L. rhamnosus YIT $0105^{\mathrm{T}}$. All strains were able to ferment D-galactose, D-glucose, D-fructose, Dmannose, D-mannitol, $\mathrm{N}$-acetylglucosamine, amygdalin, cellobiose, maltose, trehalose, D-tagatose and gluconate (weakly). All strains were able to grow at $\mathrm{pH} 4.0$ and $15{ }^{\circ} \mathrm{C}$, and hydrolyse aesculin. No strains were able to ferment erythritol, D- or L-arabinose, D- or L-xylose, D-adonitol, methyl $\beta$-D-xylopyranoside, dulcitol, inositol, methyl $\alpha$-D-mannopyranoside, inulin, glycogen, xylitol, D- or L-fucose, D- or L-arabitol, or 5-ketogluconate. None of the strains grew in $8 \% \mathrm{NaCl}$. Strains were not motile and did not produce gas from glucose, dextran from sucrose, ammonia from arginine, or reduce nitrate. + , Positive; - , negative; $w$, weakly positive reaction; ND, no data.

\begin{tabular}{|c|c|c|c|c|}
\hline Characteristic & 1 & 2 & 3 & 4 \\
\hline \multicolumn{5}{|l|}{ Growth at: } \\
\hline $10{ }^{\circ} \mathrm{C}$ & + & $\mathrm{w}$ & $\mathrm{w}$ & w \\
\hline $45^{\circ} \mathrm{C}$ & - & - & - & + \\
\hline $\mathrm{pH} 8.5$ & + & + & - & + \\
\hline Tolerance to $5 \%$ salt & + & + & - & + \\
\hline \multicolumn{5}{|l|}{ Acid production from: } \\
\hline Glycerol & + & - & - & - \\
\hline D-Ribose & + & - & + & + \\
\hline L-Sorbose & - & - & - & + \\
\hline L-Rhamnose & - & - & - & w \\
\hline D-Sorbitol & - & - & - & + \\
\hline Methyl $\alpha$-D-glucopyranoside & - & - & $\mathrm{w}$ & + \\
\hline Arbutin & + & + & + & $\mathrm{w}$ \\
\hline Salicin & + & + & + & $\mathrm{w}$ \\
\hline Lactose & - & + & + & + \\
\hline Melibiose & + & - & - & - \\
\hline Sucrose & + & $\mathrm{w}$ & + & + \\
\hline Melezitose & + & + & + & $\mathrm{w}$ \\
\hline Raffinose & + & - & - & - \\
\hline Starch & $\mathrm{w}$ & - & - & - \\
\hline Gentiobiose & + & + & + & w \\
\hline Turanose & - & - & + & + \\
\hline D-Lyxose & - & - & - & + \\
\hline 2-Ketogluconate & $\mathrm{w}$ & - & - & - \\
\hline Optical form of lactic acid & DL & $\mathrm{L}$ & $\mathrm{L}$ & $\mathrm{L}$ \\
\hline \multicolumn{5}{|l|}{ Peptidoglycan } \\
\hline Type & L-Lys-D-Asp & $\mathrm{ND}$ & L-Lys-D-Asp & ND \\
\hline meso-DAP* & - & + & - & - \\
\hline DNA G $+C$ content $(\mathrm{mol} \%)$ & 48.1 & 48.7 & 47.5 & 46.8 \\
\hline
\end{tabular}

${ }^{\star}$ DAP, Diaminopimelic acid. 
$11204^{\mathrm{T}}$ ) for $18 \mathrm{~h}$ by saponification, methylation and extraction using the method of Miller (1982) with minor modifications (Kuykendall et al., 1988). FAMEs were determined by using the MIDI system with MOORE5 of the MIS Standard Libraries. The isomers of lactic acid formed from glucose were determined with a TC D-/L-lactic acid test kit (Boehringer Mannheim).

Various phenotypic characteristics of isolate YIT $12363^{\mathrm{T}}$ differed from those of L. casei YIT $0078^{\mathrm{T}}$, L. paracasei subsp. paracasei YIT $0209^{\mathrm{T}}$ and L. rhamnosus YIT $0105^{\mathrm{T}}$. Likewise, isolate YIT $12364^{\mathrm{T}}$ had different phenotypic characteristics from L. parafarraginis YIT $12274^{\mathrm{T}}$ and $L$. rapi YIT $11204^{\mathrm{T}}$ (Tables 1,2 and 3). According to the genotypic and phenotypic data obtained, it is proposed that the novel strains should be classified as representatives of two novel Lactobacillus species: Lactobacillus saniviri sp. nov. (YIT $12363^{\mathrm{T}}$ ) and Lactobacillus senioris sp. nov. (YIT $\left.12364^{\mathrm{T}}\right)$.

\section{Description of Lactobacillus saniviri sp. nov.}

Lactobacillus saniviri (sa.ni.vi'ri. L. adj. sanus healthy; L. gen. n. viri of an adult male; N.L. gen. n. saniviri of a healthy adult male, indicating the source of the type strain).

Cells are rod-shaped $(1.0 \times 1.5-3.0 \mu \mathrm{m})$ and occur singly, in pairs or in short chains comprising three to six cells. Cells are Gram-stain-positive, non-motile, asporogenous and facultatively anaerobic. Catalase and pseudocatalase are not produced. After anaerobic growth at $37{ }^{\circ} \mathrm{C}$ for $72 \mathrm{~h}$, colonies on MRS agar are circular to slightly irregular, $1.5-2.0 \mathrm{~mm}$ in diameter and beige with a smooth surface. After aerobic growth at $37{ }^{\circ} \mathrm{C}$ for $72 \mathrm{~h}$ on blood agar, $\alpha$-haemolysis is observed. In MRS broth, growth occurs at $10{ }^{\circ} \mathrm{C}$ but not at $45^{\circ} \mathrm{C}$. Growth occurs at $\mathrm{pH} 4.0$ and $\mathrm{pH}$ 8.5. Growth occurs in the presence of $5 \% \mathrm{NaCl}$ but not in the presence of $8 \%$ $\mathrm{NaCl}$. Gas is not produced from glucose. Both L- $(49 \%)$ and D-lactate $(51 \%)$ are produced as end products from glucose.

Table 2. Differential characteristics of Lactobacillus senioris sp. nov. YIT $12364^{\top}$ and closely related lactobacilli

Strains: 1, Lactobacillus senioris sp. nov. YIT $12364^{\mathrm{T}}$; 2, L. rapi YIT $11204^{\mathrm{T}}$; 3, L. parafarraginis YIT $12274^{\mathrm{T}}$. All strains were able to ferment L-arabinose, D-ribose, D-xylose and D-glucose. No strains were able to ferment glycerol, erythritol, D-arabinose, L-xylose, D-adonitol, D-mannose, L-sorbose, L-rhamnose, dulcitol, inositol, Dmannitol, D-sorbitol, methyl $\alpha$-D-mannopyranoside, amygdalin, arbutin, salicin, cellobiose, trehalose, inulin, starch, glycogen, xylitol, gentiobiose, D-lyxose, D-tagatose, D- or L-fucose, D- or L-arabitol or 2-ketogluconate. None of the strains grew in $8 \% \mathrm{NaCl}$ or at $10{ }^{\circ} \mathrm{C}, 45{ }^{\circ} \mathrm{C}$ and $\mathrm{pH} 8.5$. Strains were not motile, did not contain meso-diaminopimelic acid in their peptidoglycan, and were not able to produce dextran from sucrose, reduce nitrate or hydrolyse aesculin. +, Positive; -, negative; w, weakly positive reaction; ND, no data.

\begin{tabular}{|lccc|}
\hline Characteristic & $\mathbf{1}$ & $\mathbf{2}$ & $\mathbf{3}$ \\
\hline Growth at: & & & \\
$15{ }^{\circ} \mathrm{C}$ & + & - & + \\
$\mathrm{pH} 4.0$ & - & - & + \\
Tolerance to 5\% salt & $\mathrm{W}$ & - \\
Ammonia production from arginine & + & + & - \\
Acid production from: & & & \\
Methyl $\beta$-D-xylopyranoside & - & - & - \\
D-Galactose & - & $\mathrm{W}$ & + \\
D-Fructose & + & + & - \\
Methyl $\alpha$-D-glucopyranoside & - & - & - \\
N-Acetylglucosamine & $\mathrm{W}$ & + & + \\
Maltose & - & - & $\mathrm{W}$ \\
Lactose & - & + & + \\
Melibiose & - & $\mathrm{W}$ & + \\
Sucrose & - & + & + \\
Melezitose & - & + & + \\
Raffinose & - & + & - \\
Turanose & - & W & W \\
Gluconate & + & W & W \\
5-Ketogluconate & - & L & DL \\
Optical form of lactic acid & L-Lys-D-Asp & L-Lys-D-Asp & ND \\
Peptidoglycan type & 39.8 & 41.6 & 42.0 \\
DNA G+C content (mol\%) & & & \\
& & & \\
\end{tabular}


Table 3. Cellular fatty acid compositions of the novel strains and genetically closely related lactobacilli

Strains: 1, L. saniviri sp. nov. YIT $12363^{\mathrm{T}}$; 2, L. paracasei subsp. paracasei $\mathrm{YIT} 0209^{\mathrm{T}}$; 3, L. senioris sp. nov. YIT $12364^{\mathrm{T}}$; 4, L. rapi YIT $11204^{\mathrm{T}}$. Values are percentages of total fatty acids. Data are from the present study. - , Not detected. DMA, dimethylacetal. ECL, equivalent chain-length.

\begin{tabular}{|c|c|c|c|c|}
\hline Fatty acid & 1 & 2 & 3 & 4 \\
\hline \multicolumn{5}{|l|}{ Saturated } \\
\hline $\mathrm{C}_{14: 0}$ & 1.16 & 11.98 & - & 1.22 \\
\hline $\mathrm{C}_{16: 0}$ & 4.1 & 17.88 & 2.23 & 18.2 \\
\hline $\mathrm{C}_{16: 0} 3 \mathrm{OH}$ & - & 0.36 & - & - \\
\hline $\mathrm{C}_{18: 0}$ & 0.82 & 0.56 & 1.53 & 0.59 \\
\hline $\mathrm{C}_{18: 0} 12 \mathrm{OH}$ & 4.42 & 4.74 & - & - \\
\hline \multicolumn{5}{|l|}{ Unsaturated } \\
\hline $\mathrm{C}_{16: 1} \omega 5 c$ & - & 0.56 & - & - \\
\hline $\mathrm{C}_{16: 1} \omega 7 c$ & - & 4.63 & - & 2.28 \\
\hline $\mathrm{C}_{18: 1} \omega 9 c$ & 56.61 & 30.32 & 57.22 & 28.18 \\
\hline $\mathrm{C}_{18: 1} \omega 7 c \mathrm{DMA}$ & 0.71 & 0.76 & 0.57 & - \\
\hline$C_{18: 2} \omega 6,9 c$ & - & - & 1.09 & - \\
\hline \multicolumn{5}{|l|}{ Cyclopropane } \\
\hline $\mathrm{C}_{19}$ сус 9,10 & 29.29 & 18.66 & 34.39 & 14.9 \\
\hline $\mathrm{C}_{19}$ cyc 11,12 & - & - & - & 5.41 \\
\hline \multicolumn{5}{|l|}{ Summed features ${ }^{*}$} \\
\hline 10 & 2.3 & 7.94 & 2.05 & 29.22 \\
\hline 12 & - & 0.54 & 0.93 & - \\
\hline Unknown fatty acid (ECL 18.199) & 0.59 & 1.05 & - & - \\
\hline
\end{tabular}

${ }^{*}$ Summed feature 10: $\mathrm{C}_{18: 1} \omega 7 c$ and/or unknown fatty acid (ECL 17.834). Summed feature 12: unknown fatty acid (ECL 18.622) and/or iso- $\mathrm{C}_{19: 0}$.

Ammonia is not produced from arginine. Nitrate is not reduced. Acid is produced from glycerol, D-ribose, Dgalactose, D-glucose, D-fructose, D-mannose, D-mannitol, $\mathrm{N}$-acetylglucosamine, amygdalin, arbutin, salicin, cellobiose, maltose, melibiose, sucrose, trehalose, melezitose (weakly), raffinose, starch (weakly), gentiobiose, D-tagatose, gluconate (weakly) and 2-ketogluconate. Aesculin is hydrolysed. Dextran is not produced from sucrose. Cells do not contain meso-diaminopimelic acid in their cell-wall peptidoglycan. Peptidoglycan structure is of the L-Lys-D-Asp type in the presence of Lys, Glu, Ala and Asp. The major cellular fatty acids $(>10 \%)$ are unsaturated fatty acid $\mathrm{C}_{18: 1} \omega 9 c$ and cyclopropane $\mathrm{C}_{19}$ cyc 9,10. Phylogenetic analysis of the $16 \mathrm{~S}$ rRNA gene sequence indicates that members of the L. casei group of lactobacilli are the closest neighbours.

The type strain, YIT $12363^{\mathrm{T}} \quad\left(=\mathrm{JCM} \quad 17471^{\mathrm{T}}=\mathrm{DSM}\right.$ $24301^{\mathrm{T}}$ ), was isolated from faeces of a healthy Japanese adult male in Tokyo, Japan. The DNA G $+\mathrm{C}$ content of the type strain is $48.7 \mathrm{~mol} \%$.

\section{Description of Lactobacillus senioris sp. nov.}

Lactobacillus senioris (se.ni'o.ris. L. gen. n. senioris of/from an elderly person, indicating the source of the type strain).

Cells are rod-shaped $(0.7 \times 1.0-10.0 \mu \mathrm{m})$ and occur singly, in pairs or in chains comprising three to four cells. Cells are
Gram-stain-positive, non-motile, asporogenous and facultatively anaerobic. Catalase and pseudocatalase are not produced. After anaerobic growth at $37{ }^{\circ} \mathrm{C}$ for $72 \mathrm{~h}$, colonies on MRS agar are circular, $1-2 \mathrm{~mm}$ in diameter and beige with a smooth or rough surface. In MRS broth, growth occurs at $15{ }^{\circ} \mathrm{C}$ but not at $10{ }^{\circ} \mathrm{C}$ or $45{ }^{\circ} \mathrm{C}$. Growth does not occur at $\mathrm{pH} 4.0$ or $\mathrm{pH} 8.5$. Growth occurs weakly in the presence of $5 \% \mathrm{NaCl}$ but not in the presence of $8 \% \mathrm{NaCl}$. Gas is produced from glucose. Both L- (72\%) and D-lactate $(28 \%)$ are produced as the end products from glucose. Ammonia is produced from arginine. Nitrate is not reduced. Acid is produced from L-arabinose, D-ribose, Dxylose, D-glucose, D-fructose, $N$-acetylglucosamine (weakly) and gluconate. Aesculin is not hydrolysed. Dextran is not produced from sucrose. Cells do not contain meso-diaminopimelic acid in their cell-wall peptidoglycan. Peptidoglycan structure is of the L-Lys-D-Asp type in the presence of Lys, Glu, Ala and Asp. The major cellular fatty acids are unsaturated fatty acid $\mathrm{C}_{18: 1} \omega 9 c$ and cyclopropane $\mathrm{C}_{19}$ cyc 9,10. Phylogenetic analysis of the $16 \mathrm{~S}$ rRNA gene sequence places the species in the L. buchneri group of lactobacilli.

The type strain, YIT $12364^{\mathrm{T}}\left(=\mathrm{JCM} 17472^{\mathrm{T}}=\mathrm{DSM} 24302^{\mathrm{T}}\right.$ ), was isolated from faeces of a 100-year-old elderly female person in Okinawa, Japan. The DNA G $+C$ content of the type strain is $41.6 \mathrm{~mol} \%$. 


\section{Acknowledgements}

We are grateful to Professor Jean P. Euzéby of the Ecole Nationale Veterinaire in Toulouse for his suggestions regarding the etymology of the species epithets.

\section{References}

Barrow, G. I. \& Feltham, R. K. (editors) (1993). Cowan and Steel's Manual for the Identification of Medical Bacteria, 3rd edn. London: Cambridge University Press.

Chao, S.-H., Tomii, Y., Watanabe, K. \& Tsai, Y.-C. (2008). Diversity of lactic acid bacteria in fermented brines used to make stinky tofu. Int $J$ Food Microbiol 123, 134-141.

Dal Bello, F., Walter, J., Hammes, W. P. \& Hertel, C. (2003). Increased complexity of the species composition of lactic acid bacteria in human feces revealed by alternative incubation condition. Microb Ecol 45, 455-463.

De Man, J. D., Rogosa, M. \& Sharpe, M. E. (1960). A medium for the cultivation of lactobacilli. J Appl Bacteriol 23, 130-135.

Ezaki, T., Hashimoto, Y. \& Yabuuchi, E. (1989). Fluorometric deoxyribonucleic acid-deoxyribonucleic acid hybridization in microdilution wells as an alternative to membrane filter hybridization in which radioisotopes are used to determine genetic relatedness among bacterial strains. Int J Syst Bacteriol 39, 224-229.

Felsenstein, J. (1985). Confidence limits on phylogenies: an approach using the bootstrap. Evolution 39, 783-791.

Fitch, W. M. (1971). Toward defining the course of evolution: minimum change for a specific tree topology. Syst Zool 20, 406-416.

Kandler, O. \& Weiss, N. (1986). Genus Lactobacillus Beijerinck 1901, $212^{\mathrm{AL}}$. In Bergey's Manual of Systematic Bacteriology, vol. 2, pp. 1209 1234. Edited by P. H. A. Sneath, N. S. Mair, M. E. Sharpe \& J. G. Holt. Baltimore: Williams \& Wilkins.

Kimura, M. (1980). A simple method for estimating evolutionary rates of base substitutions through comparative studies of nucleotide sequences. J Mol Evol 16, 111-120.

Kuykendall, L. D., Roy, M. A., O'Neill, J. J. \& Devine, T. E. (1988). Fatty acids, antibiotic resistance, and deoxyribonucleic acid homology groups of Bradyrhizobium japonicum. Int J Syst Bacteriol 38, 358-361.

Marmur, J. (1961). A procedure for the isolation of deoxyribonucleic acid from microorganisms. J Mol Biol 3, 208-218.
Mesbah, M., Premachandran, U. \& Whitman, W. B. (1989). Precise measurement of the $\mathrm{G}+\mathrm{C}$ content of deoxyribonucleic acid by highperformance liquid chromatography. Int J Syst Bacteriol 39, 159167.

Miller, L. T. (1982). Single derivatization method for routine analysis of bacterial whole-cell fatty acid methyl esters, including hydroxy acids. J Clin Microbiol 16, 584-586.

Naser, S. M., Thompson, F. L., Hoste, B., Gevers, D., Dawyndt, P., Vancanneyt, M. \& Swings, J. (2005). Application of multilocus sequence analysis (MLSA) for rapid identification of Enterococcus species based on rpoA and pheS genes. Microbiology 151, 2141-2150.

Naser, S. M., Dawyndt, P., Hoste, B., Gevers, D., Vandemeulebroecke, K., Cleenwerck, l., Vancanneyt, M. \& Swings, J. (2007). Identification of lactobacilli by pheS and rpoA gene sequence analyses. Int J Syst Evol Microbiol 57, 2777-2789.

Rzhetsky, A. \& Nei, M. (1992). A simple method for estimating and testing minimum-evolution trees. Mol Biol Evol 9, 945-967.

Saitou, N. \& Nei, M. (1987). The neighbor-joining method: a new method for reconstructing phylogenetic trees. Mol Biol Evol 4, 406425.

Schleifer, K. H. \& Kandler, O. (1972). Peptidoglycan types of bacterial cell walls and their taxonomic implications. Bacteriol Rev 36, 407-477.

Stackebrandt, E. \& Goebel, B. M. (1994). A place for DNA-DNA reassociation and 16S rRNA sequence analysis in the present species definition in bacteriology. Int J Syst Bacteriol 44, 846-849.

Tamura, K., Dudley, J., Nei, M. \& Kumar, S. (2007). MEGA4: molecular evolutionary genetics analysis (MEGA) software version 4.0. Mol Biol Evol 24, 1596-1599.

Thompson, J. D., Gibson, T. J., Plewniak, F., Jeanmougin, F. \& Higgins, D. G. (1997). The CLUSTAL_X windows interface: flexible strategies for multiple sequence alignment aided by quality analysis tools. Nucleic Acids Res 25, 4876-4882.

Walter, J., Hertel, C., Tannock, G. W., Lis, C. M., Munro, K. \& Hammes, W. P. (2001). Detection of Lactobacillus, Pediococcus, Leuconostoc, and Weissella species in human feces by using group-specific PCR primers and denaturing gradient gel electrophoresis. Appl Environ Microbiol 67, 2578-2585.

Watanabe, K., Fujimoto, J., Sasamoto, M., Dugersuren, J., Tumursuh, T. \& Demberel, S. (2008). Diversity of lactic acid bacteria and yeasts in Airag and Tarag, traditional fermented milk products of Mongolia. World J Microbiol Biotechnol 24, 1313-1325. 